\title{
Dentition damage in parrotfishes feeding on hard surfaces at Fernando de Noronha Archipelago, southwest Atlantic Ocean
}

\author{
R. M. Bonaldo ${ }^{1,2, *}$, J. P. Krajewski ${ }^{2}$, C. Sazima ${ }^{2}$, I. Sazima ${ }^{2}$ \\ ${ }^{1}$ School of Marine and Tropical Biology, James Cook University, Townsville, Queensland 4811, Australia \\ ${ }^{2}$ Departamento de Zoologia e Museu de História Natural, Caixa Postal 6109, Universidade Estadual de Campinas, 13083-970, \\ Campinas, São Paulo, Brazil
}

\begin{abstract}
Parrotfishes (Scaridae) are renowned for their beak-like dentition, which enables them to bite on coralline and rocky surfaces to feed on algae and detritus. These fishes dwell in a wide range of habitats, but most studies on parrotfish feeding behavior and ecology have been made on coral reef sites. We report on parrotfishes with damaged dentition at Fernando de Noronha, a volcanic archipelago off the coast of northeast Brazil, in the tropical southwest Atlantic Ocean. We recorded tooth damage only in adult individuals (>40 cm total length [TL]) of 3 common species (Sparisoma amplum, S. axillare and S. frondosum) in the study area. The frequency of tooth damage varied among the species: $0.85 \%$ in $S$. amplum, $2.34 \%$ in $S$. axillare and $0.76 \%$ in $S$. frondosum. Two types of tooth damage were recorded: broken teeth and the whole dental plate protruding from the mouth. Individuals with damaged dentition were recorded at 6 out of 10 study sites. The abundance of parrotfishes with tooth damage and their presence at several sites within the archipelago indicate that this is a common and predictable event in the area. The reefs of Fernando de Noronha Archipelago comprise mostly basaltic rocks, which are much harder than the calcium carbonate matrix that generally composes coral reefs where most studies on parrotfish behavior and ecology have been conducted. This may explain the absence of reports of parrotfishes with damaged teeth in the scientific literature to date.
\end{abstract}

KEY WORDS: Parrotfishes · Sparisoma - Damaged dentition - Hard surfaces · Basaltic rocks · Volcanic archipelago $\cdot$ Southwest Atlantic

\section{INTRODUCTION}

Parrotfishes (Perciformes: Scaridae) are diverse and influential herbivorous fishes in tropical and subtropical reefs and are renowned for their beak-like dentition, which they use to bite on coralline and rocky substrata to feed on algae, detritus and coral polyps (Bellwood \& Choat 1990, Bruggemann et al. 1994a,b,c, Wilson et al. 2003, Bonaldo et al. 2006). While doing so, parrotfishes usually break and ingest part of the hard substrata found on reefs (Bellwood \& Choat 1990, Bruggemann et al. 1996), indicating that they have a strong dentition (Bellwood \& Choat 1990, Prostak et al. 1991, Carr et al. 2006) which enables them to continually access their main food source during their rela- tively long life. Furthermore, parrotfishes usually have a high feeding frequency; some species have been recorded delivering up to 5 bites min $^{-1}$ against the substratum (Bellwood \& Choat 1990, Bruggemann et al. 1994a,b, Bonaldo et al. 2006). Thus, their dentition is probably exposed to a great repetitive physical stress during their lives.

Parrotfishes are found in a wide range of habitats including seagrass beds and coralline and rocky reefs, and display different feeding modes, such as scraping, browsing and/or excavating the substrate (Bellwood \& Choat 1990, Bernardi et al. 2000, Streelman et al. 2002). The current phylogeny of Scaridae proposes a gradual shift from browser species living in seagrass beds to excavators dwelling in coralline and rocky 
reefs, and finally to scrapers found exclusively in association with coral reefs (Bernardi et al. 2000, Streelman et al. 2002). Despite the wide range of parrotfish habitats, most studies on scarid feeding behavior and ecology have been conducted in coral reefs, especially in the Caribbean (Hanley 1984, Bruggemann et al. 1994a,b,c, McAfee \& Morgan 1996) and Indo-Pacific region (e.g. Bellwood \& Choat 1990, Bellwood et al. 2003). In these areas, parrotfishes feed mostly on dead and live corals (Bellwood \& Choat 1990, Bruggemann et al. 1994a,b), which are composed of calcium carbonate, i.e. sedimentary substrates (Nybakken \& Bertness 2005).

On the other hand, coral reefs in the southwestern Atlantic Ocean are reduced or absent, since the reefs in this region are composed mostly of rocky substrata that have a geological composition very distinct from that of coral reefs (Nybakken \& Bertness 2005), and are primarily made of a very hard substratum when compared with coral skeleton. The southwestern Atlantic Ocean also has a relatively high degree of endemism, including 6 parrotfish species (Moura et al. 2001, Gasparini et al. 2003, Robertson et al. 2006, Froese \& Pauly [see www.fishbase.org]). Of these 6 species, 4 belong in the genus Sparisoma (S. amplum, S. axillare, $S$. frondosum and $S$. tuiupiranga), which is restricted to, or primarily found in, the Atlantic Ocean (Bernardi et al. 2000). Sparisoma is hypothesized as a transitional group because species of this genus are found in all habitat types where parrotfishes are known to occur and display the full range of feeding modes known for Scaridae (Bernardi et al. 2000, Streelman et al. 2002). In the Atlantic Ocean, Sparisoma also has the highest species richness (13 species) (Humann \& DeLoach 2002, see also www.fishbase.org). Thus, studies on Sparisoma species could provide a better understanding of parrotfish evolution and ecology, especially in the Atlantic Ocean.

Between 2002 and 2006, we studied reef fish behavior and ecology at Fernando de Noronha Archipelago (e.g. Sazima et al. 2004, 2006, Bonaldo et al. 2006, Krajewski et al. 2006), a volcanic island group off the coast of northeast Brazil, in the tropical west Atlantic Ocean. During that 5 yr period we frequently recorded parrotfish individuals with various degrees of damaged dentition. However, even with the probable physical stress to which the dentition of scarid species is submitted during their feeding activity, no records exist to date in the scientific literature of parrotfishes with damaged dentition (D. R. Bellwood \& J. H. Choat pers comm., pers. obs).

Although parrotfish ecology and behavior have been extensively studied elsewhere (e.g. Winn \& Bardach 1957, Bellwood \& Choat 1990, Bruggemann et al. 1994a,b,c, Bernardi et al. 2000, Streelman et al. 2002), little is known about parrotfishes dwelling in rocky reef habitats (but see Ferreira et al. 1998, Bonaldo et al. 2006). Information about scarid ecology in rocky reefs, the main type of coastal habitats in western South America and Eastern Africa (Nybakken \& Bertness 2005), is instrumental in understanding the effects and the relationships between parrotfishes and the substrata on which they forage. Additionally, the study of parrotfishes in rocky reefs may provide a better understanding of their evolution and adaptation to distinct environments.

The aim of this study was to record and quantify the occurrence of damaged dentition in 3 Sparisoma species (S. amplum, $S$. axillare and $S$. frondosum), at Fernando de Noronha Archipelago. We addressed the following questions: (1) What types of dentition damage are present in the parrotfishes? (2) How abundant are individuals with damaged dentition in the study area? (3) Is there a life phase (juvenile or adult) in which damaged dentition occurs more frequently? (4) Are there particular sites where parrotfishes with damaged dentition are found?

\section{MATERIALS AND METHODS}

The field study was conducted at Fernando de Noronha Archipelago ( $\left.3^{\circ} 54^{\prime} \mathrm{S}, 32^{\circ} 25^{\prime} \mathrm{W}\right), 345 \mathrm{~km}$ off the coast of northeast Brazil (see Maida \& Ferreira 1997 for map and description) from October to November 2005 and from May to July 2006. The study was carried out at 10 sites around the archipelago (Fig. 1).

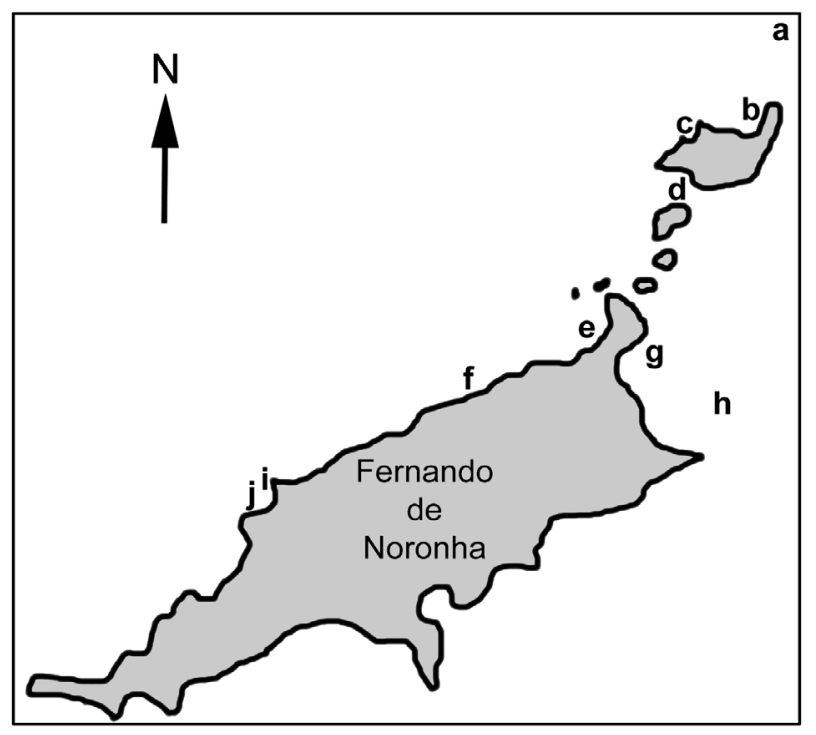

Fig. 1. Fernando de Noronha Archipelago, southwest Atlantic Ocean, showing the 10 study sites as follows: (a) Pontal do Norte, (b) Buraco do Inferno, (c) Cagarras, (d) Ressurreta, (e) Porto de Santo Antonio, (f) Ilha do Morro de Fora, (g) Buraco da Raquel (h) Pedras Secas, (i) Baia do Sancho north shore, and (j) Baia do Sancho - south shore 
Five of these sites were located around the main island of the archipelago (north and south shores of Baía do Sancho, Buraco da Raquel, Porto de Santo Antonio and Ilha do Morro de Fora); 3 were around the secondary islands (Buraco do Inferno, Cagarras, and Ressurreta), and 2 were at reefs away from islands (Caieiras and Pontal do Norte). In general, the study sites were reefs composed of volcanic (basaltic) rocks covered mostly with brown macroalgae (Dictyotaceae, Sargassum spp.) and also with red and green algae and hard coral Millepora spp. colonies. Also present were colonies of the hard coral Montastrea cavernosa, but these were rare $(<5 \%$ of the reef substratum) at most of the study sites (Bonaldo et al. 2006, J. P. Krajewski \& R. M. Bonaldo unpubl. data). Depth at the study sites ranged from 2 to $40 \mathrm{~m}$, horizontal visibility from 10 to $40 \mathrm{~m}$, and water temperature from 27 to $28^{\circ} \mathrm{C}$.

The presence of Sparisoma amplum, $S$. axillare and $S$. frondosum individuals with damaged dentition was recorded over 78 non-consecutive days while snorkelling and scuba diving. During observational sessions of 60 to $90 \mathrm{~min}$, 'scan' samplings (Altmann 1974, Lehner 1979) were used in $4600 \mathrm{~min}$ of direct observation. The relative abundance of parrotfishes with damaged dentition was estimated based on censuses done using timed transects (10 min long, $6 \mathrm{~m}$ wide). Timed transects were used to minimize observer effects and increase encounter rates (cf. Bellwood et al. 2003). The mean distance covered in 10 min was $300 \mathrm{~m}$; thus, the census areas were about $300 \mathrm{~m}$ long and $6 \mathrm{~m}$ wide. Before a census, a $6 \mathrm{~m}$ string was laid to help estimate the transect width. All censuses were conducted in the morning (08:00 to 10:00 h) to standardize any errors due to the time of day. Also, to standardize census errors, all records were made by the first author (modified from Bellwood \& Wainwright 2001, Bellwood et al. 2003).

We made a total of 91 timed transects, of which 16 were at the north shore of Baía do Sancho, 16 at the south shore of Baía do Sancho, 4 at the Buraco do Inferno, 7 at Buraco da Raquel, 8 at Cagarras, 3 at Caieiras, 16 at the Ilha do Morro de Fora, 3 at the Pontal do Norte, 11 at the Porto de Santo Antonio and 7 at the Ressurreta. Each census was carried out by swimming parallel to the rocky shores. All parrotfish individuals recorded in the transect (scanning from the bottom to the surface) were identified to species and grouped in 2 life phase categories (juveniles and adults) and 2 dentition categories (non-damaged and damaged). Care was taken to not re-count individuals. Due to difficulties with identifying juveniles to species level, all individuals less than $5 \mathrm{~cm}$ total length (TL) were named Sparisoma spp. (following Stimson et al. 2001). We classified only those individuals in which the damage was clearly seen as 'dam- aged dentition' (see 'Results' for description of the damage types); thus, our estimates of the number of individuals with damaged dentition are probably underestimated. Since parrotfishes swam and fed continuously, we were unable to quantify the different types of dentition damage during the censuses. However, we assessed the kind of damage that parrotfishes could present on their dentition by further observations in addition to those recorded in the censuses as well as from photographs and video recordings taken at the study sites.

\section{RESULTS}

We recorded 2 types of damage in the dentition of parrotfishes: (1) broken teeth and (2) jaw protruding from the mouth (Fig. 2). In the first type the dentition had missing parts (Fig. 2b). The broken teeth could be in the upper or lower jaws, or in both. The extent of the damage varied from small fractures to large sections missing in the dental plate. Moreover, the damage position in the dental plate could be at the base, middle or apex. In the second damage type the entire dental plate was dislodged in the lower jaw and was attached to the fish's mouth by a piece of flesh and skin (Fig. 2c). The protrusion angle was variable and in some extreme cases the lower dental plate hung almost loose from the mouth after the fish had taken bites at the substratum. Some individuals presented a combination of broken teeth and a protruding dental plate.

A total of 471 adult individuals of Sparisoma amplum, 939 of $S$. axillare and 1306 of $S$. frondosum were recorded during the censuses. Among the adults, 4 S. amplum $(0.85 \%), 22 \mathrm{~S}$. axillare $(2.34 \%)$ and $10 \mathrm{~S}$. frondosum $(0.76 \%)$ individuals, all larger than $40 \mathrm{~cm}$ TL, had some degree of tooth damage (Fig. 2). Individuals with damaged teeth were found at 6 of the 10 study sites. $S$. amplum and $S$. frondosum individuals with damaged teeth were recorded at 3 study sites, while $S$. axillare were recorded at 6 study sites (Table 1). Juvenile individuals of $S$. amplum (n=14), $S$. axillare $(\mathrm{n}=82)$, $S$. frondosum $(\mathrm{n}=56)$ and non-identified parrotfish species $(n=193)$ were recorded during the censuses, but none of them presented damaged dentition.

The feeding behaviour of individuals with damaged teeth was variable and seemed to be directly related to the extent of the damage. The Sparisoma species recorded at the study sites have high feeding rates (Bonaldo et al. 2006) and our impression was that those individuals with a few broken parts foraged normally, whereas those with severe damage fed little or did not feed at all. 

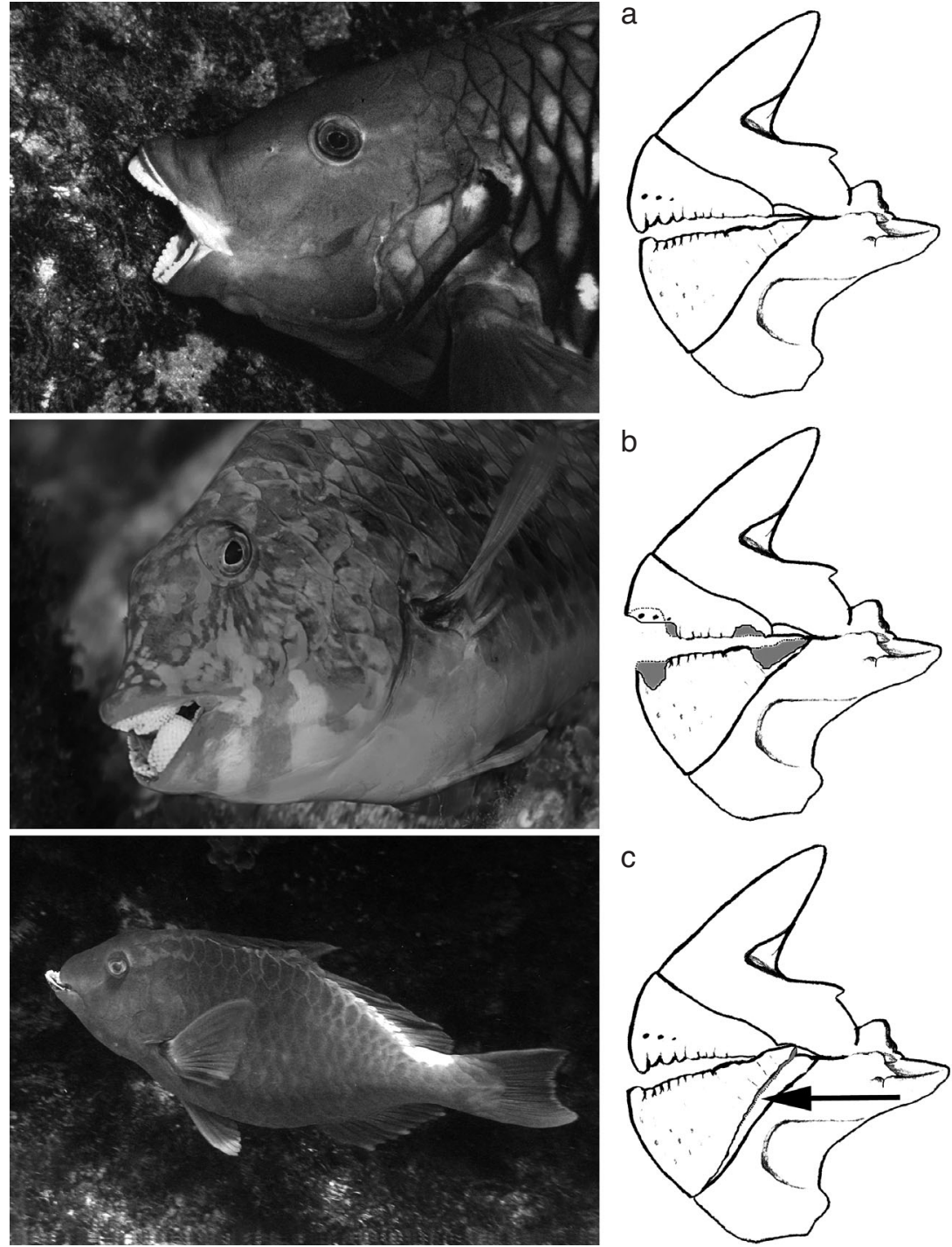

Fig. 2. (a) Sparisoma amplum individual with undamaged dentition, (b) S. axillare individual with broken teeth, (c) $S$. frondosum individual with lower teeth plate protruding from the mouth (arrow shows the point where the dentition is released from the mouth)

\section{DISCUSSION}

The frequency of individual parrotfishes with some tooth damage is considerably high (up to $12.5 \%$ at some sites) and predictable on reefs at Fernando de Noronha Archipelago. At our study sites, this can probably be attributed to the composition of the reefs, which is of volcanic origin. Since parrotfishes feed by hitting the substratum with their teeth, their dentition is probably affected and even broken while they forage over hard substrata. Thus, the 3 species of parrotfishes we studied probably damaged their teeth by foraging over the volcanic rocks (Bonaldo et al. 2006), which are considerably harder than coral reef substratum (Linsker 2003).

In addition to the hardness of the rocky substratum, it is possible that the rock rugosity further exacerbates the conditions that lead to dentition damage in parrotfishes. Rocks in Fernando de Noronha Archipelago are mostly rough with sharp protuberances (Fig. 3), against which a parrotfish has to hit hard with its teeth while feeding (Bonaldo et al. 2006, pers. obs.), especially while closing the mouth, a condition that ultimately would lead to severely damaging the dental plate. Volcanic rocks are much harder than the sedimentary rocks that usually comprise dead and live coral colonies. Thus, the absence of data on parrotfishes with damaged dentition in the current literature may be explained by the fact that most of the studies on parrotfish foraging behaviour have been conducted in the Caribbean and Indo-Pacific tropical reefs (e.g. Bruggemann et al. 1994ab,c, McAfee \& Morgan 1996), where the substratum is composed mostly of coral colonies (Nybakken \& Bertness 2005). If our hypothesis is true, we expect additional instances of parrotfishes with damaged teeth, especially within the genus Sparisoma, will be found on other volcanic reefs with few or no coral colonies or other calcium carbonate sources.

Another non-exclusive explanation of why parrotfishes with damaged teeth appear to be more common at our study sites than in coral reefs would be that there is a lack of an abundant calcium carbonate matrix, which would provide a source of calcium for the foraging fish, at Fernando de Noronha Archipelago. This nutritional deficiency could render the fish's dentition to be more prone to damage than those of parrotfishes dwelling on coral reefs. Parrotfishes are known to ingest large amounts of calcium carbonate matrix in coral reefs (Choat \& Bellwood 1990, Bruggeman et al. 1996) and this matrix may provide the nutrients needed to strengthen their dental plates, which are known to contain a high amount of calcium (Prostak et al. 1991). Some areas of Fernando de Noronha have an abundant calcium car- 
Table 1. Sparisoma amplum, S. axillare and $S$. frondosum. Mean \pm SE number (mean percentage in parentheses) of individuals of parrotfishes with damaged dentition found at 6 of the 10 study sites (damaged dentition was not apparent at Pontal do Norte, Pedros Secas, and Baia do Sancho-north shore or south shore; see Fig. 1)

\begin{tabular}{|lccc|}
\hline $\begin{array}{l}\text { Study site } \\
\text { (abbrev. in Fig. 1) }\end{array}$ & S. amplum & S. axillare & S. frondosum \\
\hline $\begin{array}{l}\text { Buraco do Inferno (b) } \\
\text { Cagarras (c) }\end{array}$ & $0.5 \pm 0.20(6.70)$ & $0.25 \pm 0.25(1.60)$ & 0 \\
$\begin{array}{l}\text { Ressurreta (d) } \\
\begin{array}{l}\text { Porto de Santo } \\
\text { Antonio (e) }\end{array}\end{array}$ & $0.80 \pm 0.10(0.86)$ & $0.75 \pm 0.16(5.6)$ & 0 \\
$\begin{array}{l}\text { Ilha do Morro de } \\
\text { Fora (f) }\end{array}$ & $0.20 \pm 0.20(7.40)$ & $0.36 \pm 0.20(1.9)$ & $0.28 \pm 0.18(2.50)$ \\
Buraco da Raquel (g) & 0 & $0.33 \pm 0.16(6.17)$ & 0 \\
\hline
\end{tabular}

colonies are most abundant compared with other reefs of the archipelago (J. P. Krajewski \& R. M. Bonaldo unpubl. data). It is possible that in the Baía do Sancho and other similar areas parrotfishes feed more constantly over a calcium carbonate matrix and, thus, injury to their teeth is absent or at least less common than at other sites of the archipelago.

Another possible explanation for the occurrence of dentition damage in Sparisoma sp. terminal phase (TP) individuals would be conspecific fights, as some parrotfish species are known to lock jaws while fighting during territorial disputes (e.g. Buckman

bonate source, such as calcareous algae (articulate or crustose), whereas other areas apparently lack such sources (e.g. Praia da Conceicao, Pontal do Norte, Buraco do Inferno, Porto de Santo Antonio) (see Bonaldo et al. 2006 for further description of substratum types found at Fernando de Noronha). Thus, it is possible that parrotfishes that live in such areas have little or no access to calcium carbonate and, thus, may have a nutritional deficit. This idea remains speculative, however, until further studies are done to evaluate the nutritional physiology, skeleton composition and resistance to physical trauma both in parrotfishes from Fernando de Noronha and at coral reefs elsewhere.

The apparent absence of juvenile parrotfishes with damaged teeth supports our suggestion that dentition damage is caused mostly by mechanical stress from feeding on hard and rough volcanic rocks of the archipelago. It appears that the constant physical stress on their dentition from feeding on hard substrata (Bonaldo et al. 2006) is cumulative and ultimately leads to the damage described herein.

The occurrence of parrotfishes with damaged teeth at Fernando de Noronha seems to be widespread in the archipelago as we found parrotfishes with broken dentition in 6 of the 10 study sites. The only site where parrotfishes did not appear to have damaged dentition was in the Baía do Sancho, where we conducted a total of 32 censuses. Baía do Sancho and its surrounding reefs are the sites in the Fernando de Noronha Archipelago where coral
\& Ogden 1973, Mumby \& Wabnitz 2002). Although this hypothesis is attractive, we never recorded any Sparisoma individual engaged in jaw locking activities during 5 yr of studying reef fish behavior at Fernando de Noronha. The only agonistic behaviour we recorded were chases among TP individuals. Thus, the fighting hypothesis does not seem compatible with our findings.

\section{CONCLUSIONS}

The conclusions of this paper are: (1) two damage types - one of which is severe-in the dentition of 3 species of Sparisoma appear to be the result of great physical trauma that occurs while constantly foraging

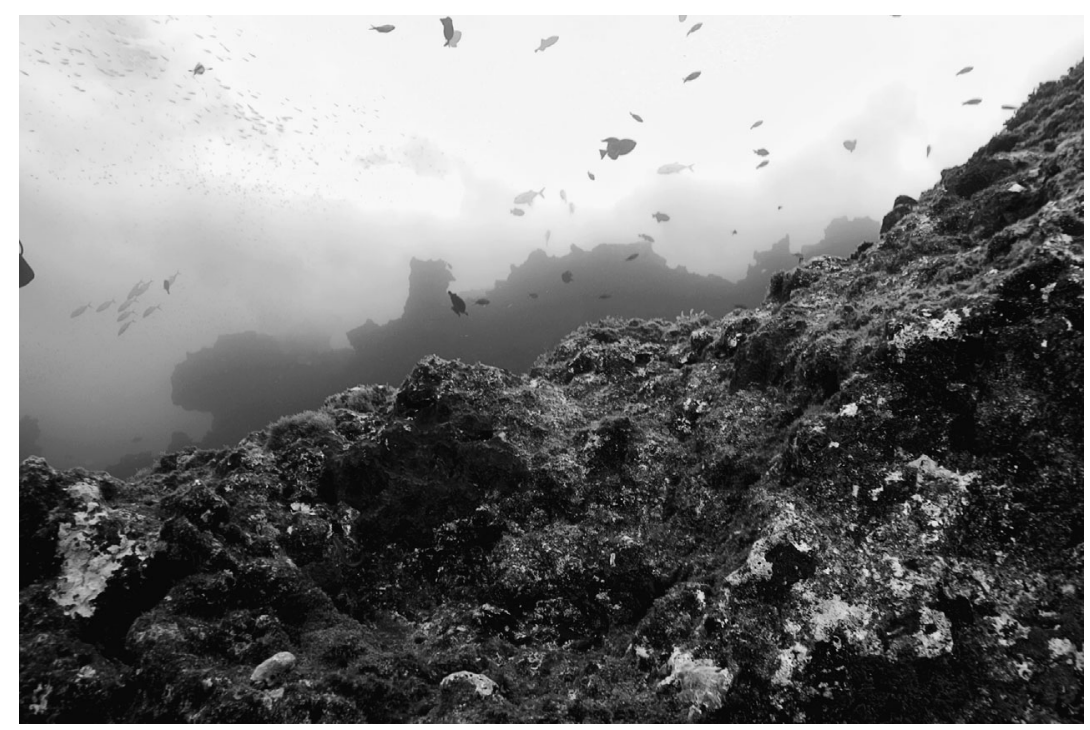

Fig. 3. A rocky reef at Fernando de Noronha Archipelago showing the irregular surface and sharp edges 
on hard and irregular reef surfaces at Fernando de Noronha Archipelago; and (2) the mechanical trauma in their dentition appears to be cumulative over the years as only adult individuals were observed to have dental damage.

Acknowledgements. We thank J. M. Silva Jr (Centro Golfinho Rotador) and the Projeto Tamar (C. Bellini and A. Grossman) for logistic support at Fernando de Noronha Archipelago; the IBAMA (M. A. Silva) for the always warm reception, logistic support and provision of study permits at the National Marine Park of Fernando de Noronha; J. H. Choat for helpful discussions and suggestions on the manuscript; L. Castell and R. Dunn for suggestions which improved the English of the manuscript, 2 anonymous reviewers for suggestions that improved the manuscript; the Águas Claras diving centre for allowing free use of their facilities; and the CAPES, CNPq, FAEP-Unicamp, FAPESP and PROAP-UNICAMP for essential financial support.

\section{LITERATURE CITED}

Altmann J (1974) Observational study of behavior: sampling methods. Behaviour 49:227-265

Bellwood DR, Choat JH (1990) A functional analysis of grazing in parrotfishes (family Scaridae): the ecological implications. Environ Biol Fishes 28:189-214

Bellwood DR, Wainwright PC (2001) Locomotion in labrid fishes: implications for habitat use and cross-shelf biogeography on the Great Barrier Reef. Coral Reefs 20:139-150

Bellwood DR, Hoey A, Choat JH (2003) Limited functional redundancy in high diversity systems: resilience and ecosystem function on coral reefs. Ecol Lett 6:281-285

Bernardi G, Robertson DR, Clifton KE, Azzurro E (2000) Molecular systematics, zoogeography, and evolutionary ecology of the Atlantic genus Sparisoma. Mol Phylogenet Evol 15:292-300

Bonaldo RM, Krajewski JP, Sazima C, Sazima I (2006) Foraging activity and resource use by three parrotfish species at Fernando de Noronha Archipelago, tropical West Atlantic. Mar Biol 149:423-433

Bruggemann JH, Begeman J, Bosma EM, Verburg P, Breeman AM (1994a) Foraging by the spotlight parrotfish Sparisoma viride. II. Intake and assimilation of food, protein and energy. Mar Ecol Prog Ser 106:57-71

Bruggemann JH, Kuyper MWM, Breeman AM (1994b) Comparative analysis of foraging and habitat use by the sympatric Caribbean parrotfish Scarus vetula and Sparisoma viride (Scaridae). Mar Ecol Prog Ser 112:51-66

Bruggemann JH, Van Oppen MJH, Breeman AM (1994c) Foraging by the spotlight parrotfish Sparisoma viride. I. Food selection in different, socially determined habitats. Mar Ecol Prog Ser 106:41-55

Bruggemann JH, Van Kessel AM, Van Rooij JM, Breeman AM (1996) Bioerosion and sediment ingestion by the Caribbean parrotfish Scarus vetula and Sparisoma viride: implications of fish size, feeding mode and habitat use. Mar Ecol Prog Ser 134:59-71

Buckman NS, Ogden JC (1973) Territorial behaviour of the striped parrotfish Scarus croicensis (Bloch Scaridae). Ecology 54:1377-1382

Carr A, Tibbetts IR, Kemp A, Truss R, Drennan J (2006) Inferring parrotfish (Teleostei: Scaridae) pharyngeal mill func- tion from dental morphology, wear, and microstructure. J Morphol 267:1147-1156

Ferreira CEL, Peret AC, Coutinho R (1998) Seasonal grazing rates and food processing by tropical herbivore fishes. J Fish Biol 53:222-235

Gasparini JL, Joyeux JC, Floeter SR (2003) Sparisoma tuiupiranga, a new species of parrotfish (Perciformes: Labroidei: Scaridae) from Brazil, with comments on the evolution of the genus. Zootaxa 384:1-14

Hanley F (1984) Time-budgeting and foraging strategy of the stoplight parrotfish Sparisoma viride Bonnaterre, in Jamaica. J Exp Mar Biol Ecol 83:159-177

Humann P, DeLoach N (2002) Reef fish identification: Florida, Caribbean and Bahamas. New World Publications, Jacksonville, FL

Krajewski JP, Bonaldo RM, Sazima C, Sazima I (2006) Foraging activity and behaviour of two goatfish species (Perciformes: Mullidae) at Fernando de Noronha Archipelago, tropical West Atlantic. Environ Biol Fishes 77:1-8

Lehner PN (ed) (1979) Handbook of ethological methods. Garland STPM, New York Press, New York

Linsker R (ed) (2003) Arquipélago Fernando de Noronha: o paraíso do vulcão. Terra Virgem, São Paulo

Maida M, Ferreira BP (1997) Coral reefs of Brazil: an overview. Proc 8th Int Coral Reef Symp 1:263-274

McAfee ST, Morgan SG (1996) Resource use by five sympatric parrotfishes in the San Blas Archipelago, Panama. Mar Biol 125:427-437

Moura RL, Figueiredo JL, Sazima I (2001) A new parrotfish (Scaridae) from Brazil, and revalidation of Sparisoma amplum (Ranzani, 1842), Sparisoma frondosum (Agassiz, 1831), Sparisoma axillare (Steindachner, 1878) and Scarus trispinosus (Valenciennes, 1840). Bull Mar Sci 68:505-524

Mumby PJ, Wabnitz CCC (2002) Spatial patterns of aggression, territory size, and harem size in five sympatric Caribbean parrotfish species. Environ Biol Fish 63: 265-279

Nybakken JW, Bertness MD (2005) Marine biology: an ecological approach, 6th edn. Benjamin Cummings, San Francisco, CA

Prostak KS, Seifert P, Skobe Z (1991) Serum fluoride level and fluoride content of enameloid. J Dent Res 70:1266-1271

Robertson DR, Karg F, Moura RL, Victor BC, Bernardi G (2006) Mechanisms of speciation and faunal enrichment in Atlantic parrotfishes. Mol Phylogenet Evol 40:795-807

Sazima I, Krajewski JP, Bonaldo RM, Sazima C (2004) Octopus cleaned by two fish species at Fernando de Noronha Archipelago, SW Atlantic. Coral Reefs 23:484

Sazima C, Krajewski JP, Bonaldo RM, Guimarães PR Jr (2006) The ubiquitous nuclear goatfish Pseudupeneus maculatus and its follower fishes at an oceanic island in the tropical West Atlantic. J Fish Biol 69:883-891

Stimson J, Larned ST, Conklin E (2001) Effects of herbivory, nutrient levels, and introduced algae on the distribution and abundance of the invasive macroalga Dictyosphaeria cavernosa in Kaneohe Bay, Hawaii. Coral Reefs 19: $343-357$

Streelman JT, Alfaro M, Westneat MW, Bellwood DR, Karl SA (2002) Evolutionary history of the parrotfishes: biogeography, ecomorphology, and comparative diversity. Evolution 56:961-971

Wilson S, Bellwood DR, Choat JH, Furnas M (2003) Detritus in coral reef ecosystems and its use by coral reef fishes. Oceanogr Mar Biol Annu Rev 41:279-309

Winn HE, Bardach JE (1957) Behaviour, sexual dichromatism, and species of parrot fishes. Science 125:885-886 